\title{
Efek perendaman rebusan Daun Sirih Merah (Piper crocatum) terhadap kekerasan permukaan resin komposit
}

\author{
Devi Puspita Handayani, Dewi Puspitasari**, Nurdiana Dewi*** \\ *Program Studi Kedokteran Gigi, Fakultas Kedokteran Gigi, Universitas Lambung Mangkurat, Banjarmasin, Kalimantan Selatan, \\ Indonesia \\ ${ }^{* * B}$ Bagian Dental Material, Fakultas Kedokteran Gigi, Universitas Lambung Mangkurat, Banjarmasin, Kalimantan Selatan, Indonesia \\ ***Bagian Biologi Mulut, Fakultas Kedokteran Gigi, Universitas Lambung Mangkurat, Banjarmasin, Kalimantan Selatan, Indonesia \\ *JI Veteran 128B, Banjarmasin, Kalimantan Selatan Indonesia; e-mail: devihandayani666@yahoo.co.id
}

Submisi: 26 April 2016; Penerimaan: 26 Mei 2016

\begin{abstract}
ABSTRAK
Penelitian ini bertujuan untuk mengetahui efek perendaman dalam rebusan daun sirih merah terhadap kekerasan permukaan resin komposit bila dibandingkan dengan obat kumur beralkohol. Penelitian ini merupakan penelitian eksperimental murni dengan post-test only with control group design. Jumlah sampel sebanyak 27 yang dibagi dalam 2 kelompok perlakuan dan 1 kelompok kontrol dengan masing-masing kelompok sebanyak 9 sampel. Kelompok perlakuan direndam dengan air rebusan daun sirih merah dan obat kumur beralkohol. Kelompok kontrol direndam dengan akuades steril. Setelah itu dilakukan pengukuran menggunakan Vickers Microhardness Tester. Hasil uji One Way Anova dan Post Hoc Bonferroni menunjukkan bahwa terdapat perbedaan bermakna nilai kekerasan permukaan resin komposit yang direndam dengan air rebusan daun sirih merah $(79,81 \pm 3,76) \mathrm{kg} / \mathrm{mm}^{2}$ dan obat kumur beralkohol $(67,11 \pm 2,51) \mathrm{kg} / \mathrm{mm}^{2}$ dengan nilai kemaknaan $(p<0,05)$. Berdasarkan penelitian yang dilakukan dapat diambil kesimpulan bahwa terdapat efek lebih rendah pada perendaman dalam rebusan daun sirih merah terhadap kekerasan permukaan resin komposit bila dibandingkan dengan obat kumur beralkohol. Nilai kekerasan permukaan resin komposit yang direndam obat kumur beralkohol lebih rendah dibandingkan air rebusan daun sirih merah.
\end{abstract}

Kata kunci: daun sirih merah (Piper crocatum), kekerasan permukaan, obat kumur beralkohol, resin komposit nanofiller

\begin{abstract}
The effect of immersion of decoction water of Red Betel Leaf (Piper crocatum) on the surface hardness of composite resin. The purpose of this study was to determine the effect of immersion of decoction water of red betel leaf on the surface hardness of composite resin compared to alcoholic mouth rinse. It was a pure experimental study with post-test only with control group design. The total samples were 27 samples divided into 2 treatment groups and 1 control group, each of which consisted of 9 samples. The treatment groups were immersed in the decoction water of red betel leaf and alcoholic mouth rinse. The control group was immersed in aquadest. After the immersion, the samples were measured using Vickers Micro hardness Tester. Analysis with one way anova and post hoc Bonferroni showed a significant difference $(p<0.05)$ on the surface hardness of composite resin after being immersed in decoction water of red betel leaf $(79,81 \pm 3,76) \mathrm{kg} / \mathrm{mm} 2$ and alcoholic mouth rinse $(67,11 \pm 2,51) \mathrm{kg} / \mathrm{mm} 2$. Based on this research, it can be concluded that there was an effect of immersion of decoction water of red betel leaf if compared with alcoholic mouth rinse. The value of surface hardness of composite resin immersed in alcoholic mouth rinse was lower than the decoction water of red betel leaf.
\end{abstract}

Keywords: red betel leaf (Piper crocatum), surface hardness, alcoholic mouthrinse, nanofiller composite resin

\section{PENDAHULUAN}

Resin komposit merupakan material tumpatan yang sering digunakan di kedokteran gigi. Komposisi resin komposit terus berkembang sejak material ini pertama kali dikenalkan. Resin komposit memiliki beberapa komponen yang terdiri dari matriks polimer organik resin, partikel pengisi anorganik (filler) dan silane coupling agent. ${ }^{1}$ Komponen silane berfungsi untuk mengikat matriks organik dan partikel pengisi sehingga menghasilkan distribusi tekanan yang merata saat menerima suatu beban. Ketahanan tekanan dan keausan resin komposit juga ditentukan oleh partikel pengisi (filler) dan rasio antara partikel pengisi (filler) dan matriks organik. ${ }^{2}$ Saat ini, banyak perubahan pada komposisi resin komposit yaitu ukuran filler yang semakin kecil sehingga mudah dipoles dan lebih kuat. Ukuran filler menentukan sifat mekanik dan penyusutan polimerisasi. ${ }^{3}$ 
Perkembangan terakhir resin komposit saat ini adalah resin komposit nanofiller. Resin komposit nanofiller berasal dari nanosilika dengan ukuran 5-20 nm serta memiliki rata-rata ukuran partikel pengisi (filler) antara 0,6-1,4 $\mu \mathrm{m} .{ }^{4}$ Matriks organik resin ini terdiri dari Bis-GMA, UDMA, TEGDMA dan Bis-EMA. Resin komposit nanofiller memberikan pengerutan yang lebih kecil, serta resisten dan retensi yang lebih besar dibandingkan jenis resin komposit lain. ${ }^{5}$

Hal-hal yang perlu dipertimbangkan dalam pemilihan jenis resin komposit, salah satunya adalah sifat mekanik yaitu kekerasan permukaan yang dapat mempengaruhi ketahanan restorasi resin komposit. ${ }^{5}$ Kekerasan permukaan resin komposit adalah ketahanan permukaan dari bahan resin komposit terhadap tekanan yang diberikan. Adanya faktor yang mempengaruhi kekerasan resin komposit akan menyebabkan resin tersebut tidak tahan lama pada rongga mulut. Idealnya resin komposit mempunyai permukaan yang halus dan kekuatan yang baik, namun tidak demikian yang terjadi karena adanya faktor-faktor yang dapat mempengaruhi kekerasan permukaan dari resin komposit tersebut. Faktor-faktor yang mempengaruhinya yaitu konsumsi minuman ringan, adanya paparan bahan kimia seperti asam, basa, garam dan alkohol melalui makanan, minuman, obat kumur dan kebersihan rongga mulut. ${ }^{6}$

Faktor yang dapat mempengaruhi kekerasan permukaan resin komposit diantaranya yaitu penggunaan obat kumur. Adanya kandungan kimia dan durasi paparan mempengaruhi matriks organik dari resin. Obat kumur telah digunakan untuk kebersihan rongga mulut. Obat kumur yang beredar di pasaran terdiri dari beberapa jenis dan memiliki kandungan alkohol maupun tidak mengandung alkohol. Obat kumur merupakan salah satu faktor yang mempengaruhi ketahanan dari restorasi gigi. Ketahanan restorasi resin komposit dapat menurun disebabkan adanya degradasi resin. Salah satu faktor yang mempengaruhi penurunan ketahanan resin komposit adalah derajat keasaman $(\mathrm{pH}){ }^{5}$

Hasil penelitian Kanan dkk menunjukkan bahwa degradasi resin komposit tidak hanya disebabkan kandungan alkohol pada obat kumur, tetapi juga $\mathrm{pH}$ dan kandungan kimia lain obat kumur. Hal ini menyebabkan terjadinya penurunan kekerasan permukaan resin. Adanya kandungan $\mathrm{pH}$ rendah pada obat kumur akan melepaskan $\mathrm{H}^{+}$dan berikatan dengan ikatan antara filler dan coupling agent sehingga ikatan tersebut lepas dan menyebabkan degradasi resin komposit. ${ }^{7,8}$ Selain obat kumur yang beredar di pasaran, terdapat juga pemanfaatan tanaman yang telah teruji memiliki sifat antibakteri dan dapat digunakan sebagai obat kumur. Salah satu tanaman obat yang ada di Indonesia adalah daun sirih merah (Piper crocatum). ${ }^{9}$

Daun sirih merah (Piper crocatum) telah dianggap sebagai tanaman obat multifungsi dan berkhasiat untuk menyembuhkan beberapa penyakit. Air rebusan dapat digunakan untuk menjaga kesehatan rongga mulut dan bau tak sedap. Di daerah Jawa, terutama di Kraton Jogjakarta, daun sirih merah telah digunakan sejak dahulu. Berdasarkan pengalaman suku Jawa, daun sirih merah mempunyai manfaat sebagai obat kumur, menyembuhkan penyakit ambeien, keputihan dan diabetes. ${ }^{9}$

Daun sirih merah mengandung hidroksikavicol, kavicol, kavibetol, allylprokatekol, karvakrol, eugenol. Selain itu juga mengandung komponen fitokimia yang terdiri dari polyphenol, flavonoid, tannin, alkaloid. Adanya kandungan fitokimia terutama katekin yang merupakan komponen dari flavonoid pada daun sirih merah dapat menghambat pertumbuhan dari bakteri termasuk Streptococcus mutans. ${ }^{10,11}$ Kandungan pada daun sirih merah merupakan senyawa fenol dan bersifat asam, hal ini kemungkinan dapat mempengaruhi sifat dari resin komposit termasuk kekerasan permukaan. ${ }^{12}$ Penelitian ini dilakukan untuk mengetahui apakah terdapat efek perendaman dalam rebusan daun sirih merah terhadap kekerasan permukaan resin komposit bila dibandingkan dengan obat kumur yang mengandung alkohol. Sehingga diharapkan dari penulisan ini dapat menambah wawasan dokter gigi dan memberi informasi bagi masyarakat mengenai efek obat kumur terhadap bahan tambalan terutama kekerasan permukaan resin komposit nanofiller. 


\section{METODE PENELITIAN}

Penelitian ini termasuk kategori penelitian eksperimental murni yang telah dilakukan di Laboratorium Mikrobiologi Fakultas Kedokteran Universitas Lambung Mangkurat, Ruang Skill Lab Fakultas Kedokteran Gigi Universitas Lambung Mangkurat dan Laboratorium Metalurgi Jurusan Teknik Material dan Metalurgi ITS pada bulan Agustus 2015. Penelitian ini adalah penelitian posttest only with control group design untuk mengetahui kekerasan permukaan resin komposit nanofiller setelah dilakukan perendaman dalam air rebusan daun sirih merah dan obat kumur beralkohol. Total sampel dalam penelitian ini sebanyak 27 sampel yang dibagi dalam 2 kelompok perlakuan dan 1 kelompok kontrol dengan masing-masing kelompok sebanyak 9 sampel. Kelompok perlakuan direndam dengan air rebusan daun sirih merah dan obat kumur beralkohol. Kelompok kontrol direndam dengan akuades steril.

Alat yang digunakan dalam penelitian ini adalah light curing unit jenis LED, cetakan yang dibuat dari self cure acrylic dengan diameter 10 $\mathrm{mm}$ dan tebal $2 \mathrm{~mm}$ berdasarkan ISO 4049 (2000), instrumen resin komposit terbuat dari teflon, object glass, gelas beker, panci, alat uji microhardness (Vickers microhardness tester) dan inkubator. Bahan yang digunakan dalam penelitian ini adalah resin komposit nanofiller, air rebusan daun sirih merah, larutan saline, obat kumur beralkohol, akuades steril dan vaselin.

Penelitian ini diawali dari tahap persiapan. Alat dan bahan dipersiapkan terlebih dahulu. Sampel resin komposit dibuat dengan diaplikasikan menggunakan instrumen resin komposit dan diletakkan pada cetakan yang di diulasi vaselin agar tidak lengket. Setelah itu, disinari selama 20 detik dengan menggunakan $L C U$. Ujung sinar harus diletakkan sedekat mungkin dengan permukaan resin. Tahap selanjutnya yaitu melakukan perendaman resin komposit nanofiller dalam gelas beker yang berisi larutan saline dan dimasukkan ke inkubator $37^{\circ} \mathrm{C}$ selama 24 jam.

Setelah 24 jam,sampel dibagi menjadi 3 kelompok dengan masing-masing 9 sampel yang dimasukkan ke dalam gelas beker yang berisi air rebusan daun sirih merah, obat kumur beralkohol dan akuades steril. Sebelumnya, air rebusan daun sirih merah dibuat dengan menggunakan daun yang masih segar sebanyak 5 lembar dengan diameter berkisar $3,5 \mathrm{~cm}$ dan direbus dengan air dua gelas $(400 \mathrm{ml})$ hingga mendidih. Setelah itu, dinginkan air rebusannya.

Setelah sampel resin komposit nanofiller dimasukkan ke masing - masing kelompok perlakuan, gelas beker tersebut diletakkan dalam inkubator selama 24 jam. Tahapan yang terakhir yaitu pengukuran hasil dengan menggunakan Vickers Microhardness Tester. Beban yang diberikan sebesar 100 gram selama 15 detik. Setelah itu dihitung dari ukuran jejas yang dihasilkan setelah diberikan tekanan oleh suatu indenter dengan mata intan berbentuk piramid dengan sisi yang berlawanan membentuk sudut $136^{\circ}$. Alat ini baik digunakan untuk area yang bulat dan kecil.

Setelah dilakukan pengukuran nilai kekerasan permukaan resin komposit nanofiller, data dievaluasi secara statistik dengan melakukan uji normalitas Shapiro-Wilk test dan uji homogenitas Levene's test. Selanjutnya dilakukan analisis parametrik dengan menggunakan uji hipotesis One way ANOVA dengan tingkat kepercayaan $95 \%(\alpha=0,05)$. Setelah itu dilanjutkan dengan analisis Post Hoc Bonferroni untuk mengetahui nilai kemaknaan. ${ }^{13}$

\section{HASIL PENELITIAN}

Hasil penelitian tentang efek perendaman dalam rebusan daun sirih merah terhadap kekerasan permukaan resin komposit bila dibandingkan dengan obat kumur beralkohol seperti terlihat pada Tabel 1.

Tabel 1. Rerata dan standar deviasi nilai kekerasan perrmukaan resin komposit setelah direndam dalam akuades steril, air rebusan daun sirih merah (Piper crocatum) dan obat kumur beralkohol

\begin{tabular}{lc}
\hline \multicolumn{1}{c}{ Kelompok } & Rerata \pm Standar Deviasi $\left(\mathrm{kg} / \mathrm{mm}^{2}\right)$ \\
\hline Akuades steril & $84,21 \pm 4,23$ \\
Air Rebusan Daun Sirih Merah & $79,81 \pm 3,76$ \\
(Piper crocatum) & \\
Obat kumur beralkohol & $67,11 \pm 2,51$ \\
\hline
\end{tabular}


Tabel 1 menunjukkan bahwa resin komposit yang direndam air rebusan daun sirih merah dan obat kumur beralkohol memiliki kekerasan permukaan lebih rendah dibandingkan akuades steril. Diagram rerata dan standar deviasi kekerasan permukaan resin komposit nanofiller pada masingmasing kelompok dapat dilihat pada Gambar 1.

Hasil pengukuran nilai kekerasan permukaan resin komposit nanofiller ini kemudian dianalisis secara statistik. Untuk mengetahui distribusi data dilakukan uji normalitas dengan Shapiro-Wilk. Hasil uji normalitas diperoleh nilai signifikansi $(p)$ pada kelompok akuades steril dengan $p>0,05$; air rebusan daun sirih merah dengan $p>0,05$; obat kumur beralkohol dengan $p>0,05$. Selanjutnya melakukan uji homogenitas dengan Levene's test dengan nilai $p>0,05$ yang berarti data homogen. Setelah dilakukan uji normalitas dan homogenitas, dilanjutkan dengan uji parametrik One Way Anova dengan tingkat kepercayaan 95\%. Hasil uji One Way Anova menunjukkan terdapat perbedaan bermakna dengan $p<0,05$. Setelah itu dilanjutkan dengan post hoc bonferroni untuk melihat perbedaan kekerasan permukaan antar kelompok. Hasil uji post hoc bonferroni didapatkan bahwa kekerasan permukaan resin komposit antara perendaman air rebusan daun sirih merah dengan obat kumur beralkohol memiliki nilai $p<0,05$. Sama halnya antara perendaman obat kumur beralkohol dengan akuades steril dan kekerasan permukaan resin komposit antara perendaman air rebusan daun sirih merah dengan akuades steril. Namun kekerasan permukaan resin komposit antara perendaman air rebusan daun sirih merah dengan akuades steril memiliki nilai perbedaan yang lebih kecil.

\section{PEMBAHASAN}

Hasil penelitian yang dilakukan dijumpai kelompok resin komposit yang direndam dengan obat kumur beralkohol memiliki nilai kekerasan permukaan paling rendah bila dibandingkan dengan kelompok resin komposit yang direndam dengan air rebusan daun sirih merah dan akuades steril. Hal ini disebabkan oleh adanya derajat keasaman $(\mathrm{pH})$. Derajat keasaman $(\mathrm{pH})$ obat kumur beralkohol tergolong lebih asam dibandingkan air rebusan daun sirih merah dan akuades steril. Hal ini sesuai dengan penelitian Diab (2007) yang menunjukkan bahwa penurunan kekerasan permukaan resin komposit tertinggi pada obat kumur beralkohol karena adanya kandungan $\mathrm{pH}$ rendah. Derajat keasaman $(\mathrm{pH})$ yang rendah akan menurunkan kekerasan permukaan resin komposit dengan adanya degradasi permukaan. Pada mulanya resin komposit akan mengalami penyerapan air. Air yang mengandung asam dapat diserap dan akan berdifusi ke dalam matriks resin. Selain disebabkan oleh $\mathrm{pH}$, penurunan kekerasan permukaan resin komposit juga disebabkan oleh adanya molekul alkohol dan kandungan kimia pada obat kumur. ${ }^{14,15}$ Sesuai dengan penelitian Kanan dkk menunjukkan bahwa degradasi resin komposit tidak hanya disebabkan oleh $\mathrm{pH}$, tetapi juga adanya alkohol dan kandungan kimia lain. Hal ini menyebabkan terjadinya penurunan kekerasan permukaan resin komposit. Kandungan alkohol pada obat kumur juga akan berdifusi ke dalam matriks resin dan dan mempengaruhi ion lainnya sehingga akan terlepas dari matriks dan mengakibatkan matriks resin terutama monomer Bis-GMA menjadi lunak dan terjadinya degradasi matriks resin komposit. ${ }^{7}$

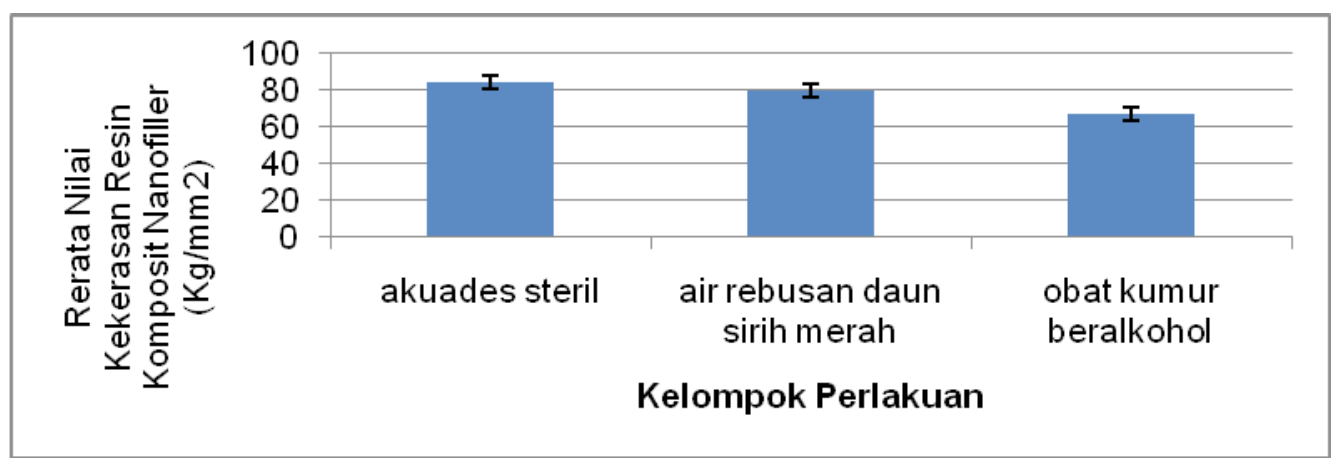

Gambar 1. Diagram hasil pengukuran kekerasan resin komposit nanofiller pada perendaman air rebusan daun sirih merah dengan obat kumur beralkohol 
Kandungan kimia didalam obat kumur beralkohol juga menyebabkan degradasi hidrolitik matriks resin komposit terutama adanya kandungan asam benzoat yang merupakan turunan dari asam karboksil. Polimer pada resin komposit mengalami degradasi karena adanya bahan kimia disekitarnya dan ketika polimer bereaksi dengan bahan kimia ke polimer yang menyebabkan terjadinya degradasi polimer. ${ }^{16}$

Selain degradasi matriks, resin komposit juga mengalami degradasi pada ikatan siloksan. Degradasi terjadi karena terputusnya ikatan siloksan Si-O-Si yang terbentuk antara filler dan coupling agent. Hal itu menyebabkan filler akan lepas dan terjadi penurunan kekerasan permukaan resin komposit. Pada obat kumur beralkohol akan terjadi pelepasan $\mathrm{H}^{+}$dan molekul alkohol dalam jumlah banyak dan akan berikatan dengan ikatan siloksan sehingga pemutusan ikatan akan lebih cepat. ${ }^{17,18}$

Berbeda halnya antara kelompok resin komposit yang direndam dengan akuades steril dengan resin komposit yang direndam dengan air rebusan daun sirih merah memiliki perbedaan kekerasan permukaan yang lebih kecil. Hal ini disebabkan oleh adanya perbedaan $\mathrm{pH}$. Derajat keasaman $(\mathrm{pH})$ air rebusan daun sirih merah tidak berbeda jauh dengan $\mathrm{pH}$ akuades steril. Derajat keasaman $(\mathrm{pH})$ air rebusan daun sirih merah berkisar 6 dan $\mathrm{pH}$ akuades steril berkisar 7. Kandungan asam lemah pada air rebusan daun sirih merah akan mengalami pelepasan $\mathrm{H}^{+}$ dalam jumlah sedikit dan akan memutuskan ikatan siloksan. ${ }^{6,8}$ Selain itu juga adanya kandungan fenol pada air rebusan daun sirih merah juga dapat menurunkan kekerasan permukaan resin komposit. Fenol memiliki gugus hidroksil (-OH) yang berikatan dengan cincin aromatik. Gugus hidroksil fenol akan mengalami pelepasan dan berikatan dengan ikatan siloksan yang mengakibatkan terputusnya ikatan siloksan Si-O-Si menjadi $\mathrm{Si}$ $\mathrm{OH}$, namun degradasi berjalan sangat lambat sehingga penurunan kekerasan berjalan sangat lambat dan membutuhkan waktu lama untuk mengalami penurunan kekerasan. Berbeda halnya pada obat kumur beralkohol, terjadinya pelepasan $\mathrm{H}^{+}$dan monomer alkohol lebih banyak yang akan berikatan dengan siloksan sehingga pemutusan ikatan siloksan dan degradasi matriks berjalan lebih cepat. Hal ini kemungkinan yang menyebabkan penurunan kekerasan permukaan resin komposit nanofiller pada air rebusan daun sirih merah lebih rendah bila disbandingkan dengan obat kumur beralkohol. ${ }^{19}$

\section{KESIMPULAN}

Kesimpulan dari penelitian ini adalah terdapat efek lebih kecil pada perendaman dalam rebusan daun sirih merah terhadap kekerasan permukaan resin komposit bila dibandingkan dengan obat kumur beralkohol. Resin komposit nanofiller yang direndam dengan obat kumur beralkohol memiliki kekerasan permukaan paling rendah. Perlunya penelitian lebih lanjut mengenai perendaman resin komposit nanofiller pada air rebusan daun sirih merah dan obat kumur beralkohol dalam beberapa waktu perendaman untuk mengetahui batas waktu jenuh pelepasan filler pada resin komposit. Saran yang dapat diberikan kepada masyarakat yaitu masyarakat dapat menggunakan obat kumur yang memiliki efek minimal pada sifat dari bahan tambalan terutama kekerasan permukaan resin komposit yang dapat mempengaruhi ketahanan material tersebut dalam rongga mulut.

\section{UCAPAN TERIMAKASIH}

Penulis menyampaikan terimakasih kepada Fakultas Kedokteran Gigi Universitas Lambung mangkurat yang telah memberikan dukungan dalam melaksanakan penelitian ini.

\section{DAFTAR PUSTAKA}

1. Feracane JL. Resin composit-State of the art. Academy of Dental Materials. 2011; 27(1): 1 10.

2. Ilie N, Hickel R. Resin composite restorative materials. Australian Dental Journal. 2011; 56(1): $59-66$. 
3. Chan KHS, Mai Y, Kim H, Tong KCT, Desmond $\mathrm{Ng}$, Hsiao JCM. Resin composit filling. Materials Journal. 2010; 3: 1228 - 1243.

4. Costa SXS, Becker AB, Rastelli ANS, Loffredo LCM, Andrade MF, Bagnato FS. Effect of Four Bleaching Regimens on Color Changes and Microhardness of Dental Nanofilled Composite. International Journal of Dentistry. 2009; 2.

5. Rocha ACD, Lima CSA, Santos MCM, Montes MAJ. Evaluation of surfce roughness of a nanofill resin composite after simulated brushing and immersion in mouthrinses, alcohol and water. Materials Research Journal. 2010; 13(1): 77 - 80.

6. Mú́nchow EA, Ferreira ACA, Machado RMM, Ramos TS. Effect of acidic solutions on the surface degradation of a micro-hybrid composite resin. Brazilian Dental Journal. 2014; 25(4): 321 - 326.

7. Kanan SM, Mohammed AK. The effect of mouthrinses on surface micro hardness of two esthetic restorative materials. Iraqi National Journal of Nursing Specialties. 2012; 25(1): $101-108$.

8. Koin PJ, Kilislioglu A, Zhou M, Drummond $\mathrm{JL}$, Hanley L. Analysis of the degradation of a model dental composites. Journal Dental Research. 2008; 87(7): $661-665$.

9. Werdhany WI, Marton A, Setyorini W. Sirih Merah. Balai Pengkajian Teknologi Pertanian Yogyakarta; 2008. 1 - 19.

10. Steenis CGGJV. Flora Pegunungan Jawa. Pusat Penelitian Biologi (LIPI). Bogor; 2006. $50-66$.

11. Erviana R, Purwono S, Mustofa. Active compounds isolated from red betel (Piper crocatum Ruiz and Pav) leaves cctive against Streptococcus Mutans through its Inhibition Effect on glucosyltransferase activity. Journal Medical Science. 2011; 43(2): 71 - 78.
12. Redha A. Flavonoid: Struktur, sifat antioksidatif dan peranannya dalam sistem biologis. Jurnal Belian. 2010; 9(2): 196 - 202.

13. Dahlan MS. Statistik untuk kedokteran dan kesehatan. Jakarta: Salemba Medika; 2013. $16-22$.

14. Diab M, Zaazou MH, Mubarak EH, Olaa MI. Effect of five commercial mouthrinses on the microhardness and color stability of two resin composite resorative materials. Austrailian Journal of Basic and Applied Sciences. 2007; 1(4): $677-674$.

15. Eliades G. Dental Material In Vivo: Aging and Related Phenomena. Chicago: Quinujisence Publishing; 2003. 117.

16. Tjuatja L, Mulyawati E, Halim FS. Perbedaan kekerasan mikro permukaan resin komposit mikrofiller dan nanofiller pada penggunaan bahan karbamid peroksida $45 \%$ dan hidrogen peroksida $38 \%$ secara in office bleaching. Journal Kedokteran Gigi. 2011; 2(4): 264 270.

17. Antonucci JM, Dickens SH, Fowler BO, Xu $\mathrm{HH}$, Mcdonough WG. Chemistry of silanes: Interfaces in dental polymers and composites. Journal of Research of the National Institute of Standards and Technology. 2005; 110(5): 541 -558 .

18. Goncalves L, Amaral CM, Poskus LT, Guimaraes JG, Silva EM. Degradation of Resin Composites in a Simulated Deep Cavity. Brazilian Dental Journal. 2014; 25(6): 536.

19. Sitanggang $P$, Tambunan $P$, Wuisan J. Uji kekerasan komposit terhadap perendaman buah jeruk nipis (Citrus Aurantifolia). Jurnal e-GiGi. 2015; 3(1): 229 - 234. 